In this connection the Committec takes occasion to express its appreciation of the efficient services rendered by the Actuary of the Institute in the mechanical preparation and business conduct of the Journal. It has been in a large measure due to his co-operation in this respect that the Committee has been enabled to prepare and issue a thoroughly revised edition of its Membership Directory which, including a compilation of the Charter and By-laws of the Institute, in a form more presentable than the earlier edition, was published in September of the past year.

\title{
Respectfully submitted,
}

Louis E. LEVY,

Philadel.phia, Pa., January 12, 19 Io.

\section{Chairman.}

\section{REPORT OF THE COMMITTEE ON SECTIONAL ARRANGE- MENTS.}

To the Board of Managers:

Thirty-four meetings were held by the Sections during the year ending September 30, I909, and considerable valuable material was obtained for publication of the INSTITUTE JournaL.

The work of the Sections was divided as follows:

Section of Physics and Chemistry ......... 8 meetings

Electrical Section.................. 8 "

Mining and Metallurgical Section.........

Mechanical and Engineering Section......... 7

Photographic Section................

In addition to these meetings an exhibition of photographs made by members was held under the auspicies of the Photographic Section. The pictures were displayed in the reading room and remained on exhibition five days.

Your committee expresses its thanks to all who have assisted in making these mcetings attractive and instructive.

Respectfully submitted,

JAMes Christie, Chairman.

Philadelphia, Pa., Jamuary i2, igio.

\section{REPORT OF THE CURATORS.}

To the Board of Managers:

During the year the lower hall was entirely repainted. The stairs were also renovated to the second floor. The work was done by the engineer and the only cost was for materials-white lead, oils, etc.

A radiator was put into the smoking room in order that it might be more comfortable in extremely cold weather. 
I56 Annual Report of Board of Managers.

Four of the panels were removed from the lecture room doors and glass was substituted. This makes it possible to observe from the outside whether there is a meeting and adds to the appearance of the Hall, besides admitting light to the inside. Some slight repairs to the building were made during the year. The room on the South side of the Lecture Room will be fitted up for conversation and committee purposes. The glassware and models will be removed, the walls and floor painted, the stove replaced by radiators and a rug put on the floor. It is hoped that this improvement will be appreciated by all who visit the Institute.

More painting will be done during the coming Summer and it is hoped that it may be possible to have the Lecture Room renovated before next season.

Respectfully submitted,

Chas. E. Ronaldson, JAMES ChRISTIE,

Curators.

Philadelphia, Pa., January 12, 1910.

\section{REPORT OF THE LIBRARY COMMITTEE.}

To the President and Members of the Franklin Institute:

The Committee on the Library respectfully submits the following report:

The following is a statement of the operations in the Library during the year ended September 30, rgog:

The following additions were made to the Library:

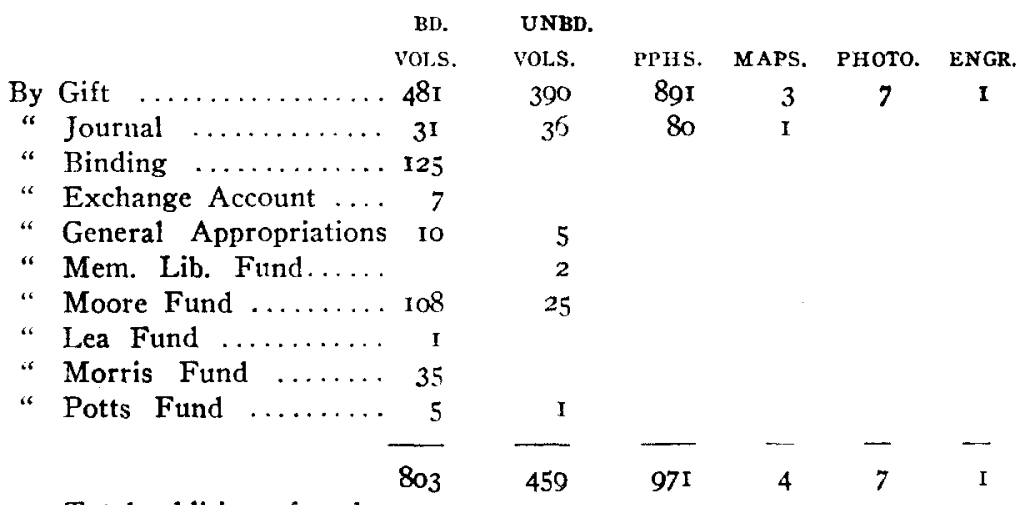

Total additions for the year, 2245 .

Gifts of books and pamphlets in large quantities or of unusual importance were received from Messrs. W. D. Anderson, John E. Carter, Walton Clark, Morris Ebert, Richard Gilpin, Carl Hering, Robert Kitchell, Waldemar Lee, Morris L. Orum, C. J. Reed, Lewis S. Ware, Prof. L. M. Haupt, Drs. Wm. H. Greene and Samuel C. Hooker, Mrs. Samuel C. Hooker, the 